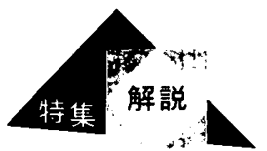

\title{
ラジオルミノグラフ法による金属中の 水素分布の可視化
}

\author{
斎 藤 英 之* \\ *室蔽工業大材料物性工学科
}

\author{
Visualization of Hydrogen Distribution in Metals by Radioluminography \\ Hideyuki Saitoh* \\ - Department of Materials Science and Engineering, Muroran Institute of Technology
}

\begin{abstract}
Recently, an imaging plate has been applied to examine the hydrogen distribution in metals, and the tritium radioluminography has been developed. In this review, the principle and the experimental procedure of this newly developed method is described. Some results such as observation of hydrogen distribution, determination of local hydrogen concentration or the measurement of the change of local hydrogen concentration are also presented.
\end{abstract} tion.

Key words : tritium radioluminography, imaging plate, hydrogen distribution, local hydrogen concentra-

\section{1. 緒言}

ラジオルミノグラフ法 (radioluminography) は, 近 年開発されたイメージングプレート (Imaging Plate, IP）を用いて放射性同位元素 (Radioisotope, RI) の 2 次元分布を観察する方法である. IP は $\alpha$ 線, $\beta$ 線, $\mathrm{X}$ 線や電子線などの放射線に対して極めて高い感度と 6 析 にも及ぶ広いダイナミックレンジを有することか

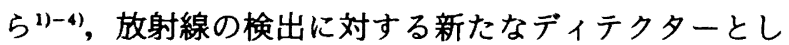
て注目を集めており，放射光 $X$ 線回折実験 ${ }^{5}$ や電子顕微 鏡用の記録媒体 ${ }^{6}$ として用いられており，放射化反応を 利用した金属中の軽元素 $(\mathrm{B}, \mathrm{C}, \mathrm{O})$ 分布の観察7)にも応 用されている。最近では，RI として水素の放射性同位 体であるトリチウムを用いたトリチウム・ラジオルミ， グラフ法により，金属中の水素分布の定量的な観察も行 われている ${ }^{8)-12)}$. 本稿では，トリチウム・ラジオルミ， グラフ法の測定原理，金属中のトリチウム分布の観察 例，および水素量の定量化について解説する。

\section{2. 測 定 原 理}

IP は, ユーロピウムを添加したバリウムフロロハラ イド系輝尽性蛍光体 $\left(\mathrm{BaFX}: \mathrm{Eu}^{2+}, \mathrm{X}=\mathrm{Cl}, \mathrm{Br}, \mathrm{I}\right)$ の 微粉末をプラスチックフィルムに塗布したものである. ラジオルミノクララフ法は, 輝尽性蛍光体の光輝尽発光 (photo-stimulated luminescence, PSL) 現象を利用し て RI 分布の観察と入射線量の測定を行っている.ここ で，PSL とは，放射線を照射した後に光を照射すると， 照射した光とは異なった波長の蛍光を発する現象であ る.PSL 発光過程の概略 ${ }^{3}$ を図 1 に示す. IP に入射し た放射線により，IP 中の価電子帯の電子が伝導帯に励 起され, $\mathrm{F}^{+}$センター（カラーセンター）に捕らえられ

\footnotetext{
- $\overline{\mathrm{T}}$ 050-8585 室間市水元町 27-1 (27-1, Mizumoto, Muroran, 0508585 Japan)
}

る.これに可視光を照射すると， $\mathrm{F}^{+}$センターに捕獲さ れていた電子が励起されて $\mathrm{Eu}^{3+}$ と再結合して $\mathrm{Eu}^{2+}$ の 励起状態となり, $\mathrm{Eu}^{2+}$ の安定状態に遷移するときに PSL が生じる. 蛍光体が $\mathrm{BaFBr}: \mathrm{Eu}^{2+}$ の場合, 図 2 に 示すように，波長 $600 \mathrm{~nm}$ 付近の光を当てると $380 \mathrm{~nm}$

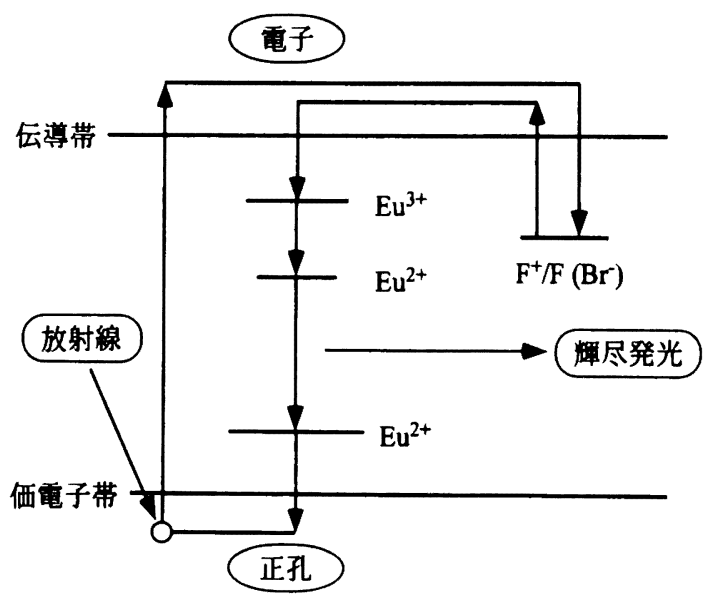

図 1 輝尽発光過程の概念図

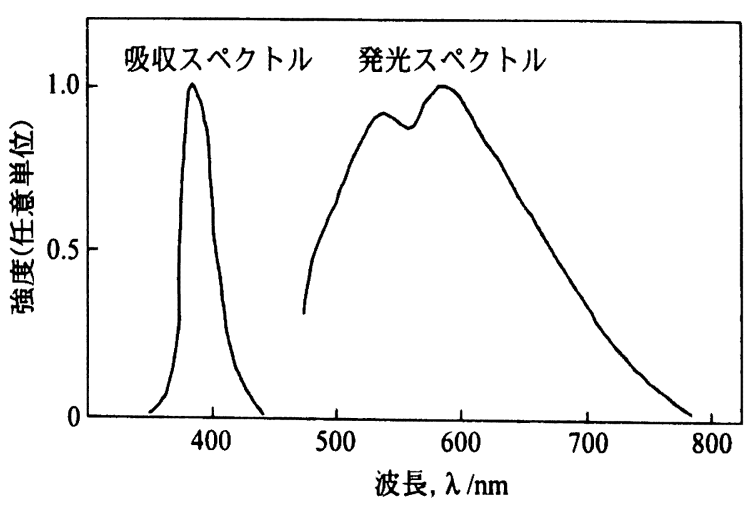

図 2 IP の吸収スペクトルと発光スペクトル 


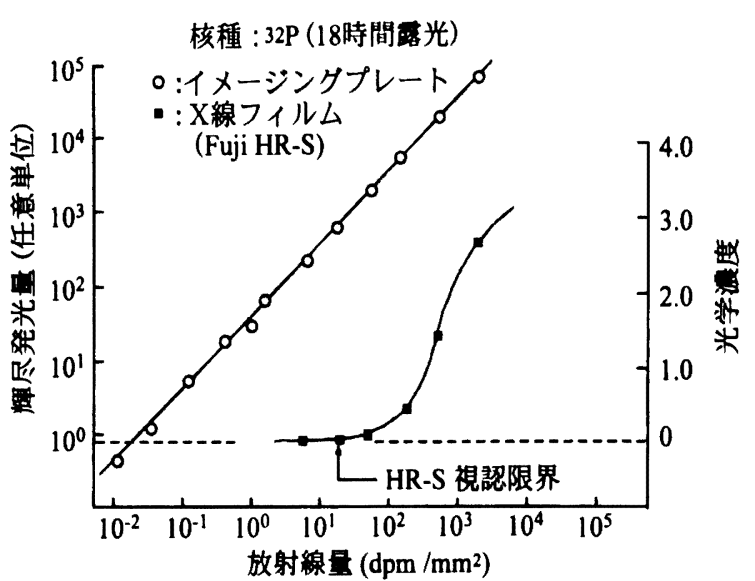

図 3 IP とX線フィルムに対寸る放射線量と輝尽発光量の 関係

にピークをもつPSL 発光が生じる2).このPSLの発光 位置と発光量から，それぞれ RIの 2 次元分布と入射線 量が測定される。IPに ${ }^{32} \mathrm{P} の \beta$ 線を照射したときの入 射線量と PSL 発光量の関係を, 従来のX線フィルムと 比較して図 $3^{{ }^{13)}}$ に示す. IP はX線フィルムよりも数百 分の一の低い線量から記録可能であり, X 線フィルム よりも高感度であることがわかる. また, 入射線量と読 み出したPSL 発光量との比例領域も広く, 定量性に優 れている.

トリチウム・ラジオルミノグラフ法は, 金属試料に添 加したトリチウムから放射される $\beta$ 線をIP で検出し， トリチウムをトレーサーとして水素の分布を観察する方 法である.トリチウムは半減期 12.3 年で ${ }^{3} \mathrm{He} に \beta$ 崩壊 し ${ }^{14)}$, この時に放射される $\beta$ 線のエネルギー分布は連 続スペクトルを示す.その最大エネルギーは 18.6

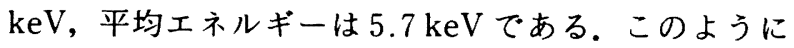
トリチウムの放射する $\beta$ 線のエネルギーは低く, 試料 中やIP 中での $\beta$ 線の飛程は短いことから, トリチウ ム・ラジオルミノグラフ法での分解能は, 用いるIP リ ーダーの読み取り精度により決定される. IP リーダー としては，例えばBAS 2000 あるい BAS 5000 (Fujix Co. Ltd.,) があるが, BAS 2000 を用いたときの分 解能は $100 \mu \mathrm{m}$ であり, BAS 5000 では $25 \mu \mathrm{m}$ である.

\section{3. 実 験 方 法}

金属試料への水素の添加は, 室温付近での水素添加に よく用いられている電気化学的陰極チャージ法により行 われている.この方法は, 硫酸や水酸化ナトリウムの電 解液を電気分解した際に陰極から発生する水素を, 陰極 として用いた試料に吸収させる方法である. 電解液とし て硫酸を用いた場合には, 多量の水素を添加できるが, 試料にダメジを与えやすい. 水酸化ナトリウムを電解 液とした場合は, おだやかに水素が添加されるので, 水 素添加量は減少するものの試料にダメージを与える心配 は少ない．本稿で解説する実験では，電解液としてトリ チウムを含む 0.1 規定の $\mathrm{NaOH}$ 水溶液が用いられてお り, 電流密度 $20 \mathrm{~mA} / \mathrm{cm}^{2} に て 2 \sim 4 \mathrm{~h}$ 電解チャージを行 って水素が添加されている。 なお, 電解液中のトリチウ
ム（T）原子とプロチウム（H）原子の数比は, トリチ ウムの放射線強度にもよるが, $10^{-5} \sim 10^{-6}$ であり, 試料 に添加される水素の大部分はプロチウムである。

トリチウムを添加した試料を IP（Fujix TR 2040）に 乗せて露光することにより，トリチウムから放射される $\beta$ 線の線量はIPに記録される. 簬光はIP用カセット に入れて保管するだけでも十分であるが, 露光時間が長 い場合には, シールディングボックス（Fujix BASSHB 2040）中に保管して環境放射線の影響を防止す る.なお, IPで用いられる蛍光体は湿気に弱いため, 通常の IP では表面にプラスチックの保䘫層がコーティ ングされているが, トリチウムから放射される低エネル ギーの $\beta$ 線は保讙層を通過できないため, トリチウ ム・ラジオルミノグラフィでは保護層が除去してあるト リチウム専用のIP を用いる必要がある.

露光終了後 IP から試料を取り去り, IP リーダーを 用いて $\beta$ 線の入射位置と入射線量を, それぞれ PSL 発 光の位置と発光量として読みとることにより, 試料表面 上でのトリチウムの 2 次元分布が得られる.

\section{4. ラジオルミノグラフィによるトリチウム 分布の観察結果}

\section{1 純バナジウム中のトリチウム分布 ${ }^{9), 101}$}

図 4 (a) は, 板状の純バナジウムにトリチウムを添加 した後, IPに $24 \mathrm{~h}$ 露光して得られたトリチウム・ラシ オルミノグラフである。この図では, PSL 強度の高い 領域は暗く，低い領域は明るく表示してある.すなわ ち，図中で暗く観察される領域および明るく観察される 領域は, それぞれトリチウム濃度の高い領域および低い 領域である。試料表面におけるトリチウムの分布は不均 一であり，濃度分布は結晶粒に依存する様子が観察され る.図 4(b) は図 4(a) 中の A-Bで示した線上での PSL 強度のラインプロファイルであり, 試料表面上のトリチ ウムの相対濃度を知ることができる. 図 4 (c) はラジオ ルミノグラフを観察した領域と同じ場所の SEM 組織写 真である．金属組織とトリチウム分布がよく対応してお り，トリチウム濃度は結晶粒に依存して変化しているこ とが確かめられる。図 4 (d) は図 4 (c) 中の四角で囲った 部分の拡大像である. トリチウム濃度の高い結晶粒では 微細な水素化物が高密度に析出し, トリチウム濃度の低 い結晶粒では粗大な水素化物が低密度に析出している。 このように, 結晶粒ごとに水素濃度が異なるのは, 結晶 粒に依存して水素化物の析出形態が異なるためであるこ とがわかる.なお, 電子チャンネリングパターン (ECP) の測定結果から, 水素濃度の低い領域の結晶粒 は（111）面であり, 水素濃度の高い結晶粒では（001） 面であることが明らかにされている。

図 5 は純バナジウムの別な試料から得られたラジオル ミノグラフである。この図においてもトリチウム濃度の 高い領域は暗く，低い領域は明るく表示してある，得ら れた PSL 強度から, 図 5 中の (1) (6)で示す領域にお ける水素濃度が求められた。 まず, 得られた PSL 強度 を $\beta$ 線強度に換算する.このためには，8段階のレベル の既知のトリチウム濃度の領域を含むプラスチックフィ ルムであるトリチウム・マイクロスケール (Amer- 

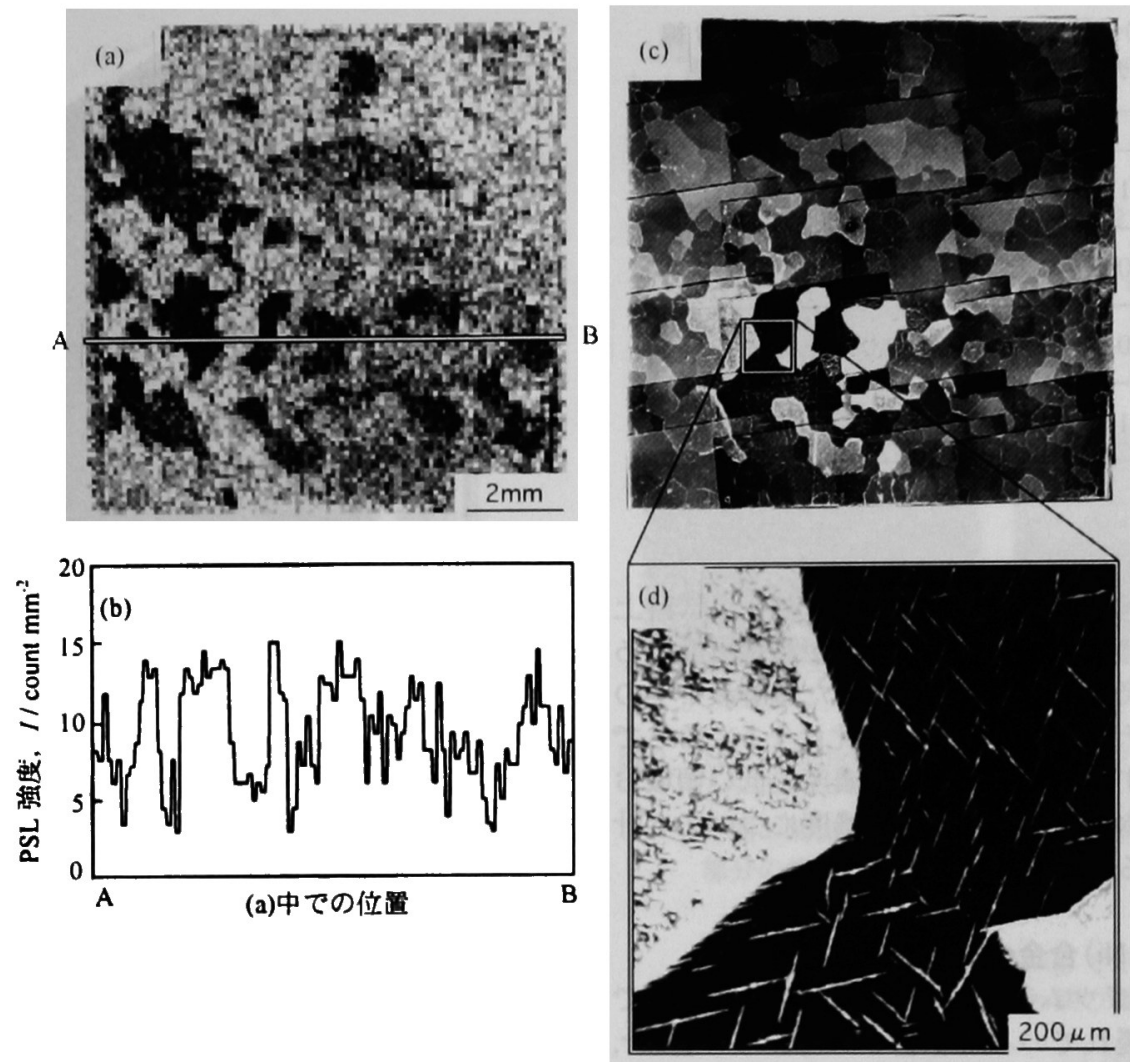

図 4 （a）純バナジウムのラジオルミノグラフ，(b) 試料表面での PSL 強度の変化, (c) SEM 組織写真, (d) 四角で囲った部分の拡大図

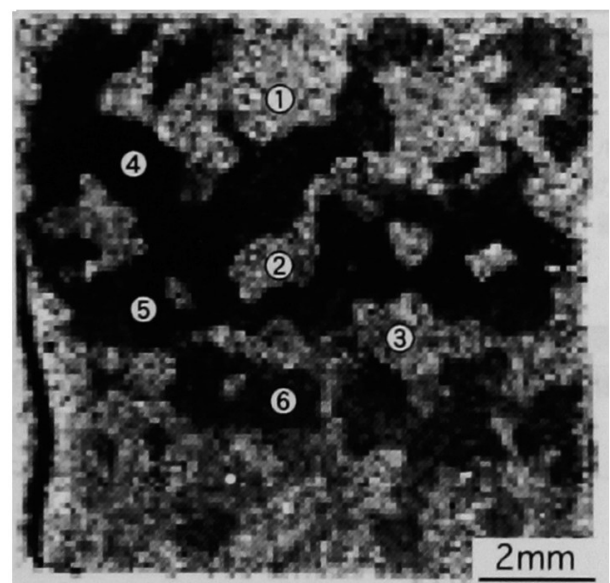

図 5 純バナジウムのラジオルミノグラフ

sham RPA 506）がトリチウム濃度の標準試料として用 いられた。 マイクロスケールのラジオルミノグラフと， 得られたPSL 強度と $\beta$ 線強度の関係を図 6 に示す。卜 リチウム濃度の異なる 8 つのブロックの存在が確認で き, また, PSL 強度と $\beta$ 線強度は比例することがわか る.すなわち, マイクロスケールと試料を同時に IP に 乗せて露光することにより, マイクロスケールの PSL 強度を基準にして, 試料上での PSL 強度を $\beta$ 線強度に 換算することができる。 $\beta$ 線強度がわかれば試料表面か ら $\beta$ 線の飛程までの深さにあるトリチウム原子の数が 計算できるので, $\beta$ 線強度をトリチウム濃度に換算する ことができる. 金属中での $\beta$ 線の飛程は, Gledhill ${ }^{15)} に$ (a)
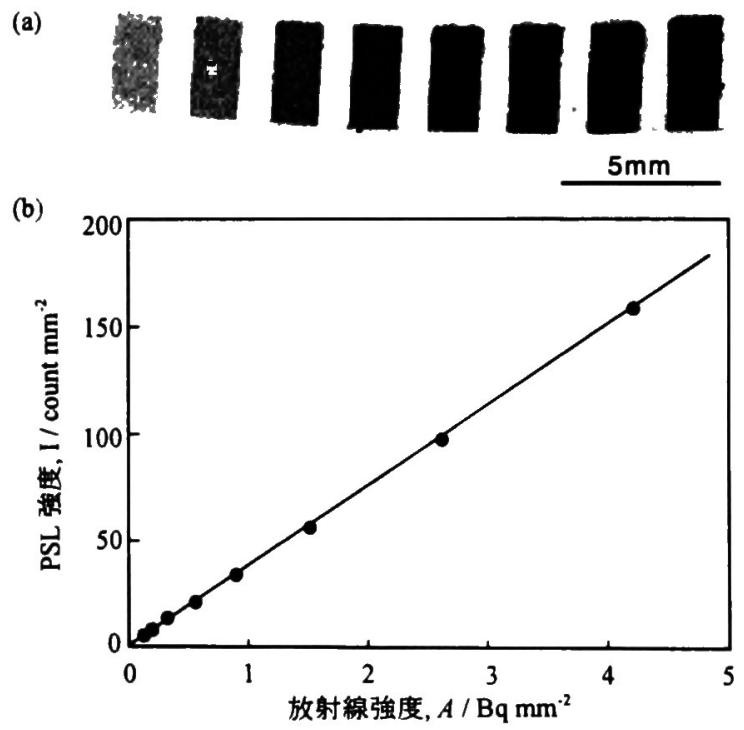

図 6 （a）トリチウム・マイクロスケールのラジオル ミノグラフ, (b) PSL 強度と $\beta$ 線強度の関係

より得られた電子線に対するエネルギーと飛程の関係式 を用いて計算する.トリチウムの $\beta$ 線は連続スペクト ルを示すので金属中の飛程を厳密に決定することは難し いが, $\beta$ 線の平均エネルギーを用いることにより，バナ ジウム中の $\beta$ 線の飛程は $0.18 \mu \mathrm{m}$ と計算される.

表 1 に, 図 5 中の (1) (6)で示す領域における PSL 強度, トリチウムの放射線強度, およびトリチウム濃度 
表 1 図 5 中の (1)〜6)で示した領域の PSL 強度, $\beta$ 線 強度,トリチウム濃度および水素濃度

\begin{tabular}{l|cccccc}
\hline & 11 & $(2)$ & $(3)$ & $(4)$ & (5) & (6) \\
\hline $\begin{array}{l}\text { PSL 強度 } \\
I / \text { count mm }\end{array}$ & 11.4 & 12.8 & 13.4 & 31.4 & 24.6 & 20.2 \\
\hline $\begin{array}{l}\text { 放射線強度 } \\
A / \mathrm{Bq} \mathrm{mm}\end{array}$ & 0.29 & 0.32 & 0.34 & 0.82 & 0.64 & 0.52 \\
\hline $\begin{array}{l}{[\mathrm{T}] \text { 濃度 }} \\
C_{\mathrm{I}} / \text { mass ppb }\end{array}$ & 0.74 & 0.81 & 0.86 & 2.08 & 1.62 & 1.32 \\
\hline $\begin{array}{l}{[\mathrm{H}] \text { 濃度 }} \\
C_{\mathrm{H}} / \text { mass ppm }\end{array}$ & 159 & 177 & 187 & 450 & 351 & 285 \\
\hline
\end{tabular}

を示す、このように，IPを用いることにより，試料上 の局所的な領域におけるトリチウム濃度が測定可能であ る.さらに，この実験の水素添加に用いた電解液中での トリチウムとプロチウムの原子の数の比は $1.5 \times 10^{-6}$ で あったことを考慮すると, トリチウム濃度の低い領域お よび高い領域での水素（プロチウム）濃度についても計 算することができる。

\section{$4.2 \mathrm{~V}_{3.5}(\mathrm{Zr}, \mathrm{Ti}, \mathrm{Ni})$ 合金のトリチウム分布 ${ }^{11)}$}

図 7 (a) は, バナジウム基プロチウム吸蔵合金の中で 初期活性化特性が優れていると報告されている $\mathrm{V}_{3.5}(\mathrm{Zr}$, $\mathrm{Ti}, \mathrm{Ni}$ ) 合金にトリチウムを添加した後, IP に $24 \mathrm{~h}$ 露光 して得られたトリチウム・ラジオルミノグラフである. 図 7(b) は図 7 (a) 中の 4 角で囲った領域の拡大像であ り, 図 7 (c) は図 7(b) と同じ場所の SEM 写真である. この合金は BCC 相と C 14 型ラーベス粒界相の 2 相か らなっており, SEM 写真で網目状に明るく観察される のがラーベス粒界相である。トリチウム分布は微細組織 と対応しており，ラーベス粒界相上ではトリチウム濃度 は高く，BCC 相上ではトリチウム濃度は低く観察され た. 図 7(b)中の (1), (2) (BCC 相) および (3), (4)（ラー ベス相）の位置でのトリチウム濃度および水素（プロチ ウム) 濃度を表 2 に示す。水素濃度は $\mathrm{BCC}$ 相では 1.5 $\mathrm{mol} \%$ ，ラーベス相では $2.3 \mathrm{~mol} \%$ と求められた。この ことから，この合金の初期活性化が容易であるのは，ラ 一ベス粒界相からの水素の優先的な浸透によることが明 らかにされた。

\section{3 トリチウム分布の経時変化 ${ }^{12)}$}

ラジオルミノグラフィでは, 試料表面での局所的な水 素濃度の測定が可能であるが, さらに, 局所的な領域で の水素濃度の時間変化も測定可能である. 図 8(a) は V$47.5 \mathrm{~mol} \% \mathrm{Ti}-5 \mathrm{~mol} \% \mathrm{Fe}$ 合金のトリチウム・ラジオル ミノグラフである. 図 8(b) は, IP に $24 \mathrm{~h}$ の露光を繰り 返し行って得られた図 8(a)中の (1) および (2) で示した 領域でのトリチウムの $\beta$ 線強度の経時変化である. ま た，第 1 回目に測定された值を 1 として規格化した $\beta$ 線強度の変化を図 $8(\mathrm{c})$ に示す。この図から, 水素濃度 の高い領域の方が低い領域に比べて水素濃度の減少の割 合の大きいことが示されている.

\section{4 深さ方向でのトリチウム分布 ${ }^{12)}$}

図 9(a) は, V-5 mol\% $\mathrm{Fe}$ 合金のトリチウム・ラジオ (a)
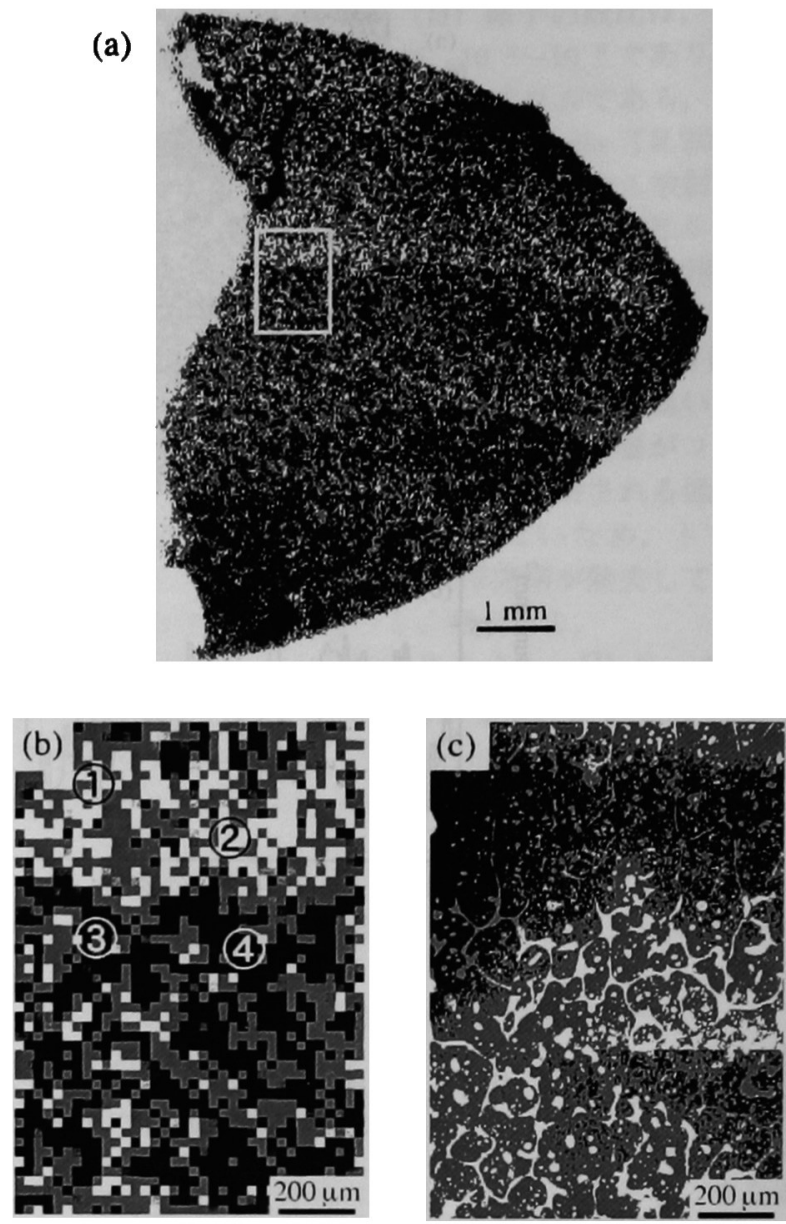

図 7 (a) $\mathrm{V}_{3.5}(\mathrm{Zr}, \mathrm{Ti}, \mathrm{Ni})$ 合金のラジオルミノグラフ, （b）四角で囲った部分の拡大図，(c)（b）と同じ 位置の SEM 組織写真

表 2 図 7 (b) 中の (1) (4) で示した領域の $\beta$ 線強度, トリ チウム濃度および水素濃度

\begin{tabular}{|c|c|c|c|c|}
\hline & (1) & (2) & (3) & (4) \\
\hline 放射線強度, $A$ / Bq mr & 10.65 & 9.83 & 16.72 & 17.15 \\
\hline [T] 濃度, $C_{\mathrm{T}} / \mathrm{mol} \mathrm{ppm}$ & 0.46 & 0.42 & 0.72 & 0.74 \\
\hline$[\mathrm{H}]$ 濃度, $C_{\mathrm{H}} / \mathrm{mol} \%$ & 1.5 & 1.3 & 2.3 & 2.3 \\
\hline
\end{tabular}

ルミノグラフであり，深さ方向のトリチウム分布を示し ている。これは，図 9(b)に示すように，柱状試料の側 面および底面をエポキシ樹脂にて絶縁被覆して上面のみ からトリチウムをチャージした後，トリチウムをチャー ジした面と垂直に試料を切断して IP に露光することに より得られている. 図 9(a)中の (1)〜(3)で示した領域に おけるトリチウムの放射線強度から求めたトリチウム濃 度を表 3 に示す.トリチウムを添加した側の領域 (1) と， そこから最も離れた領域 (3)でのトリチウム濃度に変化 がみられないことから, 試料中での水素分布は平衡状態 にある.しかしながら，(2)に示す領域ではトリチウム 濃度が高くなっていた。この断面における鉄の分布を波 長分散型 X 線分析法（WDX）により調べたところ, 図 9 (c) に示されるように, 図 9(a) 中の四角で囲った領域 における $\mathrm{Fe}-\mathrm{K} \alpha$ 線を用いた鉄の分布とトリチウムの分 

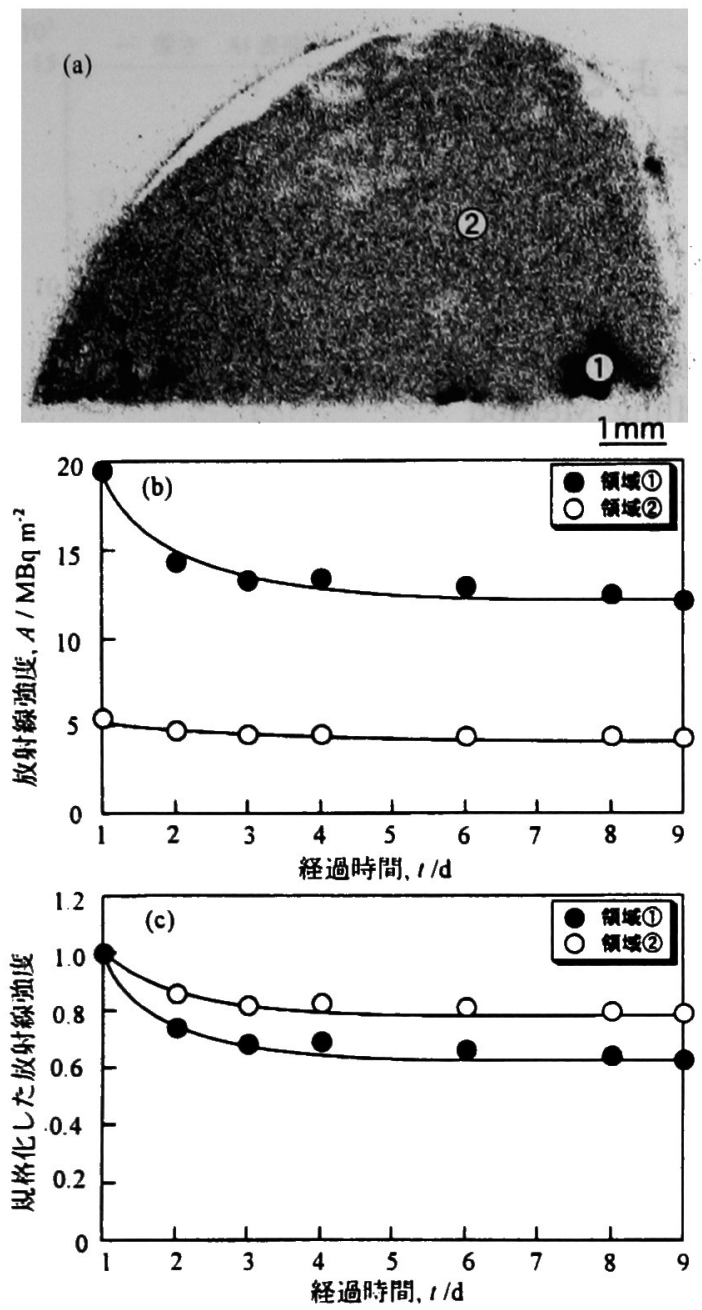

図 8 (a) $\mathrm{V}-47.5 \mathrm{~mol} \% \mathrm{Ti}-5 \mathrm{~mol} \% \mathrm{Fe}$ 合金のラジオルミノグ ラフ，(b) (1) および(2)の領域でのトリチウムの $\beta$ 線強 度の経時変化，（c） 1 回目の值で規格化した $\beta$ 線強度の 経時変化

布には相関が見られたすなわち，トリチウム濃度の高 い領域では鉄の濃度は低く，トリチウム濃度の低い領域 では鉄の濃度が高いことが示されている。

\section{5. ま と}

イメージングプレートを用いるトリチウム・ラジオル ミノグラフ法の測定原理・方法およびバナジウム中のト リチウム分布を視覚的に観察した結果について解説し た.この方法では, 微視的な領域でのトリチウム濃度の 定量や, その時間変化の測定のできることが大きな特徴 と言える。しかしながら, ラジオルミノグラフ法の分解 能は $25 \mu \mathrm{m}$ 程度と，あまり高いとは言えない. 他の方 法を併用し，それぞれの方法の特徴を生かしながら目的 に応じて使い分けることが必要である。

\section{参 考 文 献}

1）宮原淳二, 加藤久豊: 応用物理, 53, 884 (1984).
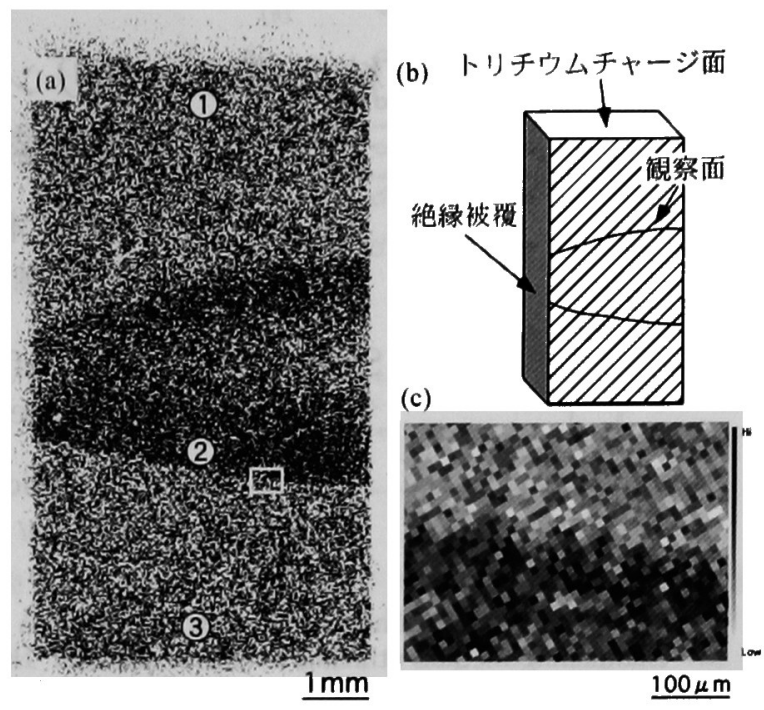

図 9 (a) $\mathrm{V}-5 \mathrm{~mol} \% \mathrm{Fe}$ 合金の断面のラジオルミノグラフ, (b)トリチウムを添加した面とトリチウム分布を観察し た面の関係，(c) $\mathrm{Fe}-\mathrm{K} \boldsymbol{\alpha}$ 線による(a)中の四角で囲った 部分の鉄の分布

表 3 図 9 (a)中の (1)〜(3)で示した領域の トリチウム濃度と鉄の濃度

\begin{tabular}{l|ccc}
\hline & 1 & $(2)$ & $(3)$ \\
\hline$[\mathrm{T}]$ 濃度, $C_{\mathrm{T}} / \mathrm{mol} \mathrm{ppb}$ & 78 & 96 & 76 \\
{$[\mathrm{Fe}]$ 濃度, $C_{\mathrm{Fe}} / \mathrm{mol} \%$} & 5.4 & 4.5 & - \\
\hline
\end{tabular}

2）宮原淳二，雨宮慶幸，松下 正：物理学会誌，45，398 (1990).

3）宮原淳二：固体物理，30，674（1995）.

4）雨宮慶幸：金属学会セミナーテキスト「X線による物質 構造の解析法」, 日本金属学会, p 59,（1993）。

5）雨宮慶幸, 大隅一政, 竹村謙一，村上洋一，川田 肇： 固体物理，29，789 (1994)。

6）進藤大輔：金属学会会報，30，809 (1991).

7）谷口政行，源内規夫，今北 毅：鉄と鋼， 85, 90 (1999).

8）斎藤英之：金属学会セミナーテキスト「最新の水素の検 出法と水素脆化防止法」, 日本金属学会, p 33, (1999).

9) H. Saitoh, T. Hishi, T. Misawa, T. Ohnishi, Y. Noya T. Matsuzaki and T. Watanabe : J. Nucl. Mater., 258263, 1404 (1998).

10) H. Saitoh, T. Misawa, Y. Noya and T. Ohnishi : Mater. Trans. JIM , 40, 692 (1999).

11）斎藤英之, 長沼裕朗, 三澤俊平, 田村卓也, 栗岩貴寛, 亀川厚則, 岡田益男, 大西俊之：日本金属学会誌，63， 1085 (1999).

12）本間啓史，斎藤英之，三澤俊平，大西俊之：日本金属学 会誌, 64, 295 (2000).

13） BAS Technical Information No.2, フジ写真フィルム (株)

14) Tables of Radioactive Isotopes, Ed. by V. S. Shirley, John Wiley \& Sons, Inc., (1986).

15) J. A. Gledhill : J. Phys. A., 6, 1420 (1973).

(2000 年 1 月 31 日受理) 